\title{
Dual effect of metformin on growth inhibition and oestradiol production in breast cancer cells
}

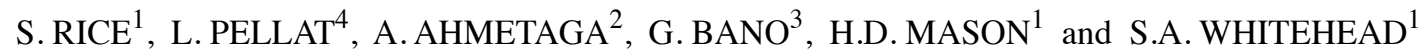 \\ ${ }^{1}$ Division of Biomedical Sciences, ${ }^{2}$ MBBS5 Programme, St. George's University of London; \\ ${ }^{3}$ Thomas Addison Unit, St. George's Hospital, Cranmer Terrace, London SW17 ORE; \\ ${ }^{4}$ Bromley College of F\&HE, Bromley Campus, Rookery Lane, Bromley BR2 8HE, UK
}

Received December 16, 2014; Accepted February 3, 2015

DOI: $10.3892 /$ ijmm.2015.2108

\begin{abstract}
Evidence has been accumulating for a role for metformin in reducing breast cancer risk in post-menopausal women. It inhibits growth of breast cancer cells via several mechanisms, primarily the AMPK/mTOR signalling pathway. Another possible protective mechanism may be the ability of metformin to inhibit aromatase activity. In the present study, we investigated the effects of metformin on the basal growth of MCF-7 cells, after oestradiol $\left(\mathrm{E}_{2}\right)$ stimulation and after the inhibition of mTOR by rapamycin. Secondly, we investigated the effects of metformin on the activity of a number of steroidogenic enzymes and the mRNA expression of aromatase and steroid sulphatase (STS). High doses of metformin significantly inhibited both basal and oestrogen-stimulated cell division. Low-dose rapamycin $\left(10^{-10} \mathrm{M}\right)$ did not inhibit growth, but the addition of metformin induced a significant reduction in growth. High-dose rapamycin $\left(10^{-8} \mathrm{M}\right)$ inhibited growth, and this was further attenuated by the addition of metformin. Exposure to low $\left(10^{-7} \mathrm{M}\right)$ and high $\left(10^{-4} \mathrm{M}\right)$ doses of metformin for 7-10 days significantly reduced the conversion of androstenedione (ANDRO) and testosterone (TESTO) (both requiring aromatase), but not the conversion of oestrone or oestrone sulphate (ES) via 17 $\beta$-hydroxysteroid dehydrogenase/ sulphatase to $E_{2}$. This attenuation was via a downregulation in the expression of total aromatase mRNA and promoter II, whilst the expression of sulphatase was unaffected by metformin. In conclusion, plasma levels of metformin have a dual therapeutic action, first by directly inhibiting cell proliferation which can
\end{abstract}

Correspondence to: Dr Suman Rice, Division of Biomedical Sciences, St. George's University of London, Cranmer Terrace, London SW17 ORE, UK

E-mail: srice@sgul.ac.uk

Abbreviations: ANDRO, androstenedione; $\mathrm{E}_{1}$, oestrone, ES, oestrone sulphate; $\mathrm{E}_{2}$, oestradiol; HSD, hydroxysteroid dehydrogenase; STS, steroid sulphatase; TESTO, testosterone

Key words: metformin, breast cancer, rapamycin, aromatase be augmented by rapamycin analogues, and secondly, by inhibiting aromatase activity and reducing the local conversion of androgens to $\mathrm{E}_{2}$.

\section{Introduction}

Metformin belongs to the biguanide class of oral hypoglycemic agents and is widely used in the treatment of type 2 diabetes mellitus (1). Early observational studies have suggested a link between metformin use and a reduced risk of cancer (2) and, since then, evidence has been accumulating for an anti-neoplastic role for metformin (1,3-5). The evidence that metformin reduces the risk of breast cancer has been mixed, although a recent meta-analysis supported a protective effect of metformin on breast cancer risk in post-menopausal women with diabetes (6).

Several studies have shown the metformin inhibits the growth of breast cancer cells both in vitro and in vivo (7-10), although high doses of metformin are required for this growth inhibition. Various mechanisms have been attributed to the anti-proliferative action of metformin (11), but perhaps the best investigated is the energy sensor pathway, the AMPK/mTOR signalling pathway (12). mTOR signalling is increased in many types of human cancer, causing malignant progression (13), but metformin inhibits mTOR by activating AMPK which negatively regulates mTOR (11). There is evidence that metformin also reduces HER-2 protein expression (overexpressed in $20 \%$ of breast cancer cases) via mTOR (14). Other actions attributed to metformin are the inhibition of cyclin D1, the activation of the tumour suppressor gene, p53, and the apoptosis and inhibition of the IGF-1 signalling pathway (11).

Metformin may also reduce breast cancer risk through its ability to inhibit aromatase expression and activity in breast tissue. Breast tissue can convert circulating androgens of adrenal origin to estrogens and $>60 \%$ of oestrogen-dependent breast carcinomas have higher levels of aromatase mRNA expression and activity compared with non-malignant tissue (15). This increase is due to an increase in the transcription of alternative promoters, primarily promoter II (PII) and promoter I.3 (PI.3) (16). Third generation aromatase inhibitors, such as anastrozole and letrozole, are commonly used in the treatment of post-menopausal breast cancer (17); however, acquired resistance to these drugs is a recurring problem in 
treatment (18). Metformin has be shown to inhibit aromatase (CYP19al) expression in human breast adipose stromal cells through the activation of AMPK (19), and subsequent studies have shown that metformin also reduces PII/PI.3 promoterspecific transcripts for aromatase (20).

The aim of this study was two-fold: firstly, to investigate the effects of metformin on the basal and oestradiol $\left(\mathrm{E}_{2}\right)$-stimulated growth of MCF-7 cells and the combined action of the mTOR inhibitor, rapamycin, and metformin on cell growth. Secondly, to investigate the effects of low-dose metformin (one that would be achieved during metformin therapy) on both the expression and the activity of a number of steroidogenic enzymatic pathways. These included aromatase, which converts androstenedione (ANDRO) and testosterone (TESTO) to $\mathrm{E}_{2}$ and the steroid sulphatase (STS) pathway which converts circulating oestrone sulphate $(\mathrm{ES})$ into oestrone $\left(\mathrm{E}_{1}\right)$, which is then converted to $\mathrm{E}_{2}$ by $17 \beta$-hydroxysteroid dehydrogenase (17 $\beta$-HSD) (Fig. 1).

\section{Materials and methods}

MCF-7 cell culture. ER-positive MCF-7 cells were purchased from the European Collection of Cell Cultures, Salisbury, UK (in partnership with Sigma-Aldrich, Gillingham, Dorset, UK). The initial stocks of MCF-7 cells were between passages 8 and 10. They were cultured in Dulbecco's modified Eagle's medium (DMEM) with $10 \%$ fetal calf serum (FCS), $2 \mathrm{mM}$ glutamate, $100 \mathrm{IU} / \mathrm{ml}$ penicillin and $100 \mu \mathrm{g} / \mathrm{ml}$ streptomycin (all reagents from Sigma-Aldrich) at $37^{\circ} \mathrm{C}$ in a fully humidified atmosphere containing $5 \% \mathrm{CO}_{2}$. Experiments were performed using 2.5\% charcoal-stripped FCS. The diluents used to make up stock solutions were added to the control wells at the appropriate concentrations.

Cell growth assays. Growth was assessed by MTT assay as previously described (21). Cells were plated (day 1) in 96-well plates at a concentration of 5,000 cells $/ 250 \mu 1$ medium, a density previously determined to be the optimal value to obtain good growth curves without reaching confluence during the culture time (22). The optical density was measured on day 2 in 8 wells using a plate reader (EL808; BioTek UK, Potton, Bedfordshire, UK) and drugs were added to triplicate wells in a standard $10 \mu \mathrm{l}$ volume/dose. On day 5 , the final measurement was made. Growth was quantified by taking the ratio of the mean optical density measured on day 5 to the mean optical density measured on day 2 , and the data were normalized to the appropriate controls. Metformin was added at 6 different doses $\left(10^{-2}-10^{-6} \mathrm{M}\right)$ with or without $\mathrm{E}_{2}\left(10^{-7} \mathrm{M}\right)$, and at 4 different doses $\left(10^{-2}-10^{-4} \mathrm{M}\right)$ in the presence of rapamycin $\left(10^{-8} \mathrm{M}\right.$ or $\left.10^{-10} \mathrm{M}\right)$. All drugs were purchased from Sigma-Aldrich.

Steroid enzyme assays. Steroid enzyme activity was determined using an 'in-house' radioimmunoassay (RIA) to measure the conversion of ANDRO, TESTO, ES and $\mathrm{E}_{1}$ to $E_{2}$ on days 3,7 and 10 of cell culture cells with/without metformin. The cells were cultured at a density of $5 \times 10^{4}$ cells/ well in 12-well dishes and left overnight. Metformin at $10^{-7}$ and $10^{-4} \mathrm{M}$ was added the following day followed by incubation for the relevant culture time. On days 3, 7 and 10, the steroid substrates (all at a concentration of $10^{-8} \mathrm{M}$ ) were added for $4 \mathrm{~h}$ to 6 wells before the removal of the medium for the measurement of $E_{2}$ levels. These were measured in duplicate as previously described $(23,24)$. The cross-reactivity of the $E_{2}$ antiserum with $\mathrm{E}_{1}$ and $\mathrm{ES}$ was 19.88 and $9.2 \%$, respectively, and appropriate corrections for the cross-reactions were made.

Reverse transcription-quantitative polymerase chain reaction (RT-qPCR) assays. RT-qPCR assay was performed to assess the effect of metformin on aromatase and STS mRNA expression. The cells were plated at $1 \times 10^{5}$ cells/well into 3 culture plates (6-well) and left overnight. The following day, duplicate wells were treated with metformin at $10^{-7}$ and $10^{-4} \mathrm{M}$ and left for 3,7 and 10 days, with medium and treatments replenished on those days. On the relevant days, the medium was removed, the cells were washed with sterile phosphate-buffered saline (PBS) and lysed, and the RNA extracted and reverse transcribed into cDNA as previously described (25). qPCR was performed using the Bio-Rad CFX real-time cycler (Bio-Rad, Hercules, CA, USA). Duplicate PCR reactions were performed with SYBR ${ }^{\mathrm{TM}}$-Green I master mix (Agilent Technologies, Santa Clara, CA, USA) using $L 19$ (mitochondrial ribosomal protein L19) as the reference gene. All primers (obtained from Sigma Custom Products, Haverhill, Suffolk, UK) were annealed at $60^{\circ} \mathrm{C}$, and the procedures for the PCR assays and L19 and aromatase sequences were as previously described (26). Sequences for the $S T S$ primers were: forward, 5'-ACTGCAACGCCTACTTAAATG-3' and reverse, 5'-AGGGTCTGGGTGTGTCTGTC-3' (NM_000351) (27). Sequences for $P I I$ primers were as previously described (25), and were used at a primer concentration of $300 \mathrm{nM}$ and annealing temperature of $59^{\circ} \mathrm{C}$.

Statistical evaluation. All data represent the means \pm SEM of duplicate/triplicate observations from a minimum of 3 or more independent experiments. Statistical significance was determined by ANOVA followed by post-hoc Tukey's multiple comparison tests, multiple unpaired t-tests, or unpaired t-test were used when 2 groups were compared (depending on the design of the experiment). When comparing to normalized control values, a one-sample t-test was used. Statistical significance was set at $\mathrm{P} \leq 0.05$. Relative gene expression from the RT-qPCR data were analysed using the $\Delta \Delta \mathrm{Ct}$ method if the amplification efficiencies of the reactions were $100 \pm 5 \%$. For reactions where the amplification efficiency fell outside this range, the Pfaffl method was used (28).

\section{Results}

Effect of metformin on basal and $E_{2}$-stimulated growth of MCF-7 cells. Metformin at the 2 highest doses $\left[10^{-2} \mathrm{M}\right.$ $(1.65 \mathrm{~g} / \mathrm{l})$ and $\left.5 \times 10^{-3} \mathrm{M}(828 \mathrm{mg} / \mathrm{l})\right]$ inhibited the basal growth of MCF-7 cells ( $\mathrm{p}=0.0004, \mathrm{p}=0.001$, Tukey's multiple comparison; Fig. 2A). $\mathrm{E}_{2}$, as expected, significantly stimulated the growth of MCF-7 cells $(p=0.0098$, one-sample t-test). Metformin at $10^{-2} \mathrm{M}$ significantly reduced the $\mathrm{E}_{2}$-stimulated increase in growth to below basal levels $(\mathrm{p}=0.001$, unpaired $\mathrm{t}$-test) and the next highest dose of metformin $\left(5 \times 10^{-3} \mathrm{M}\right)$ also attenuated $\mathrm{E}_{2}$-induced growth to basal levels $(\mathrm{p}=0.01$, unpaired t-test; Fig. 2B).

These doses of metformin are much higher than those measured in plasma. These have been reported to be $1.7 \mathrm{mg} / \mathrm{l}$ 


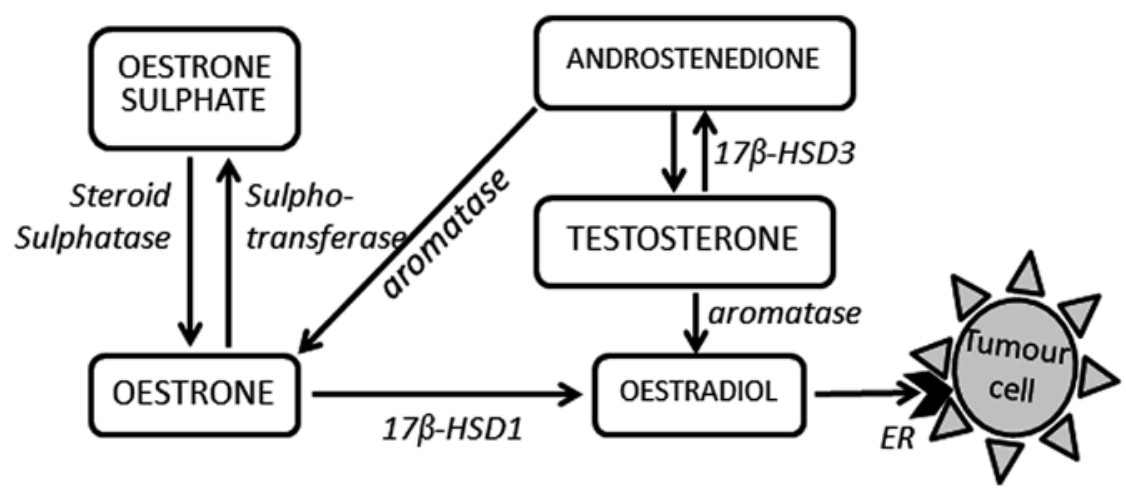

Figure 1. Illustration of the key enzymes involved in the aromatase and steroid sulphatase pathways that are used to synthesise oestradiol in breast cancer cells. ER, oestrogen receptor; 17ß-HSD, 17- $\beta$ hydroxysteroid dehydrogenase [Adapted from Foster et al (40)].
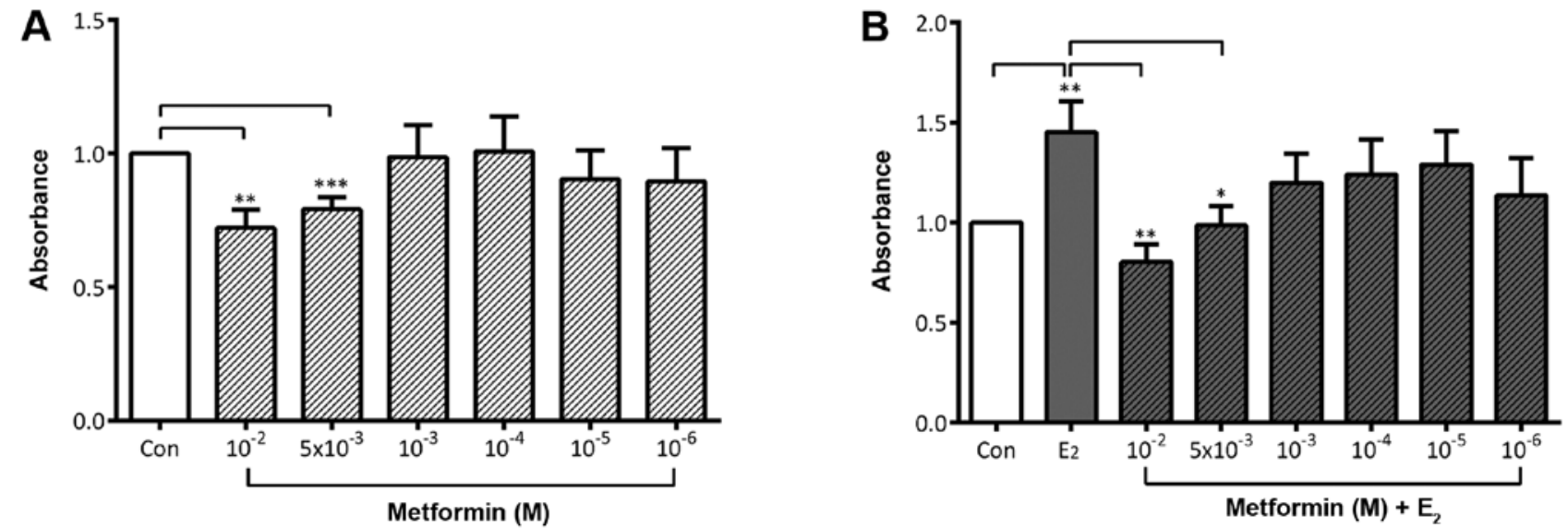

Figure 2. (A) Graph depicting the effect of increasing doses of metformin [from $1 \mu \mathrm{M}\left(10^{-6} \mathrm{M}\right)$ to $\left.10 \mathrm{mM}\left(10^{-2} \mathrm{M}\right)\right]$ on the basal growth of MCF-7 cells. The 2 highest doses of metformin $(10$ and $5 \mathrm{mM})$ significantly attenuated basal cell growth $(\mathrm{n}=5$ experiments $)\left({ }^{* *} \mathrm{p}<0.005\right.$ and ${ }^{* * * *} \mathrm{p}<0.0005$, Tukey's multiple comparisons). (B) Treatment of the cells with oestradiol $\left(\mathrm{E}_{2}\right)(100 \mathrm{nM})$ significantly increased the growth of the cells (" $\mathrm{p}<0.005$, one-sample $\mathrm{t}$-test). This was inhibited to basal levels by the addition of metformin at the 2 highest doses used $(\mathrm{n}=4$ experiments) ( $\mathrm{p}<0.05$, Tukey's multiple comparisons and two-tailed unpaired $\mathrm{t}$-test).

$\left(10^{-5} \mathrm{M}\right) 3 \mathrm{~h}$ after an oral dose of $850 \mathrm{mg}$ metformin, but being undectable in plasma after $24 \mathrm{~h}(29)$, and a mean steady state of $0.576 \mathrm{ng} / \mathrm{l}\left(3.5 \times 10^{-9} \mathrm{M}\right)$ after $1 \mathrm{~g}$ metformin taken twice daily for several months (30). Either higher doses of metformin may be required in vitro to maintain sufficient levels of the drug over a period of days or the growth inhibition is simply a pharmacological effect of the drug.

Effect of metformin on rapamycin-dependent inhibition of $M C F-7$ growth. Low-dose rapamycin $\left(10^{-10} \mathrm{M}\right)$ reduced the basal growth of MCF-7, although not significantly (Fig. 3A); however, the combination of rapamycin and metformin induced a significant reduction in basal cell growth $(\mathrm{p}<0.05$, one-sample t-test; Fig. 3A), even with doses of metformin that on their own $\left(5 \times 10^{-3} \mathrm{M}\right.$ and $\left.10^{-4} \mathrm{M}\right)$ had no effect on growth (Fig. 2A). High-dose rapamycin $\left(10^{-8} \mathrm{M}\right)$ significantly inhibited growth ( $\mathrm{p}=0.003$, one-sample t-test), and in combination with $10^{-2} \mathrm{M}$ metformin produced an additive inhibition of growth compared to rapamycin alone $(p=0.007$, unpaired t-test; Fig. 3B). This effect of metformin at all doses was even more pronounced with the higher concentration of rapamycin $\left(10^{-8} \mathrm{M}\right)(\mathrm{p}<0.0001$ ANOVA, Tukey's multiple comparison t-test; Fig. 3B).

Effect of metformin on MCF-7 steroid activity. Metformin at both doses had no effect on the conversion of $\mathrm{E}_{1}$ (Fig. 4A) or ES (Fig. 4B) to $\mathrm{E}_{2}$; by contrast, however, metformin inhibited the conversion of ANDRO (Fig. 4C) and TESTO to $\mathrm{E}_{2}$ (Fig. 4D). Very low-dose metformin $\left(10^{-7} \mathrm{M}\right)$ decreased $\mathrm{E}_{2}$ levels by days 7 and 10 with both ANDRO (Fig. 4C) and TESTO (Fig. 4D) as substrates $\left(\mathrm{p}<0.005\right.$, multiple t-tests). Metformin $\left(10^{-4} \mathrm{M}\right)$ also inhibited the conversion of ANDRO (Fig. 4C) and TESTO (Fig. 4D) to $\mathrm{E}_{2}$, but this was more marked (particularly for TESTO) and occurred sooner, i.e., the decrease in $E_{2}$ was noticeable by day 3 ( $p<0.0005$, multiple t-tests; Fig. 4C and D). Interestingly, the overall levels of $\mathrm{E}_{2}$ were higher in the experiments where $\mathrm{E}_{1}$ or ES were used as substrates compared to ANDRO or TESTO.

Effect of metformin on the mRNA expression of steroid enzymes. Metformin, particularly at the dose of $10^{-4} \mathrm{M}$, had a marked effect on aromatase mRNA expression, with signifi- 

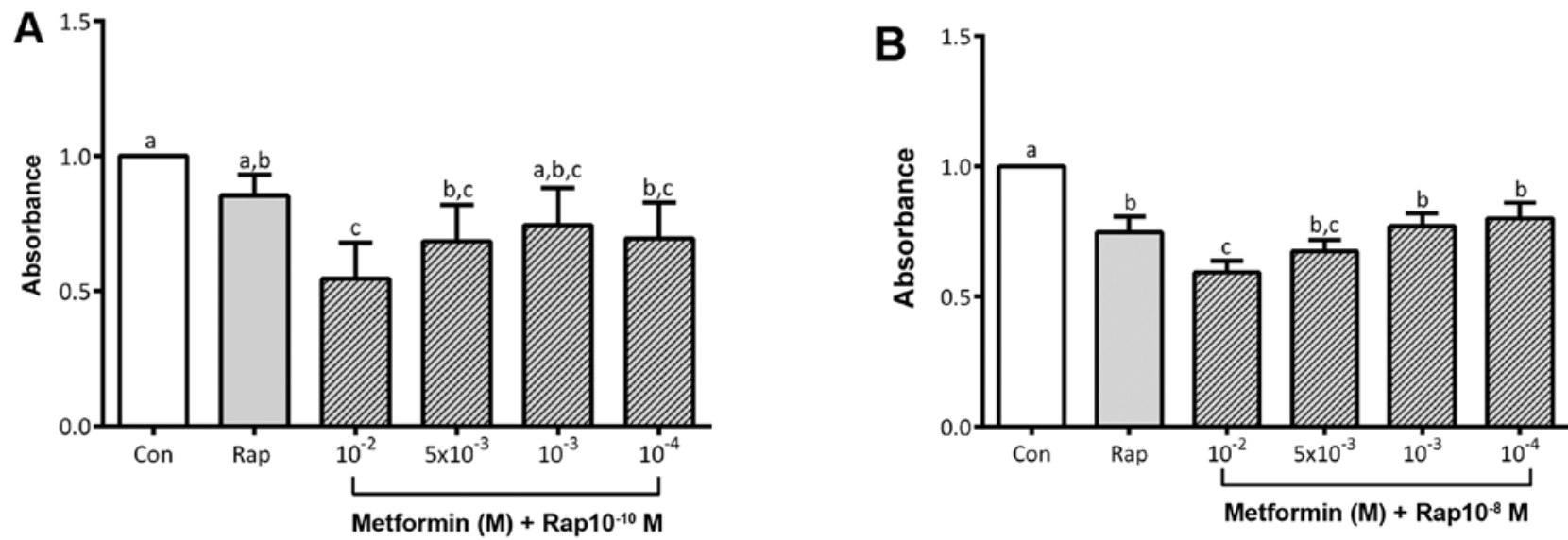

Figure 3. (A) Cells were treated with rapamycin $(0.1 \mathrm{nM}) \pm$ metformin at various doses from $10^{-2}$ to $10^{-4} \mathrm{M}$. On its own, rapamycin at a low dose did not significantly reduce growth, but the addition of the highest dose of metformin $(10 \mathrm{mM})$ significantly reduced growth to below basal levels ("p $<0.05$, unpaired $\mathrm{t}$-test) Rapamycin, in combination with lower doses of metformin, had no effect on growth ( $\mathrm{n}=4$ ) (different letters on the graph denote significance). (B) Cells were treated as described in (A), except that the dose of rapamycin was increased to $100 \mathrm{nM}$, which significantly reduced basal growth. This was further attenuated in the presence of metformin at $10 \mathrm{mM}$, but not the other doses $(\mathrm{n}=3)$ (different letters on the graph denote significance).
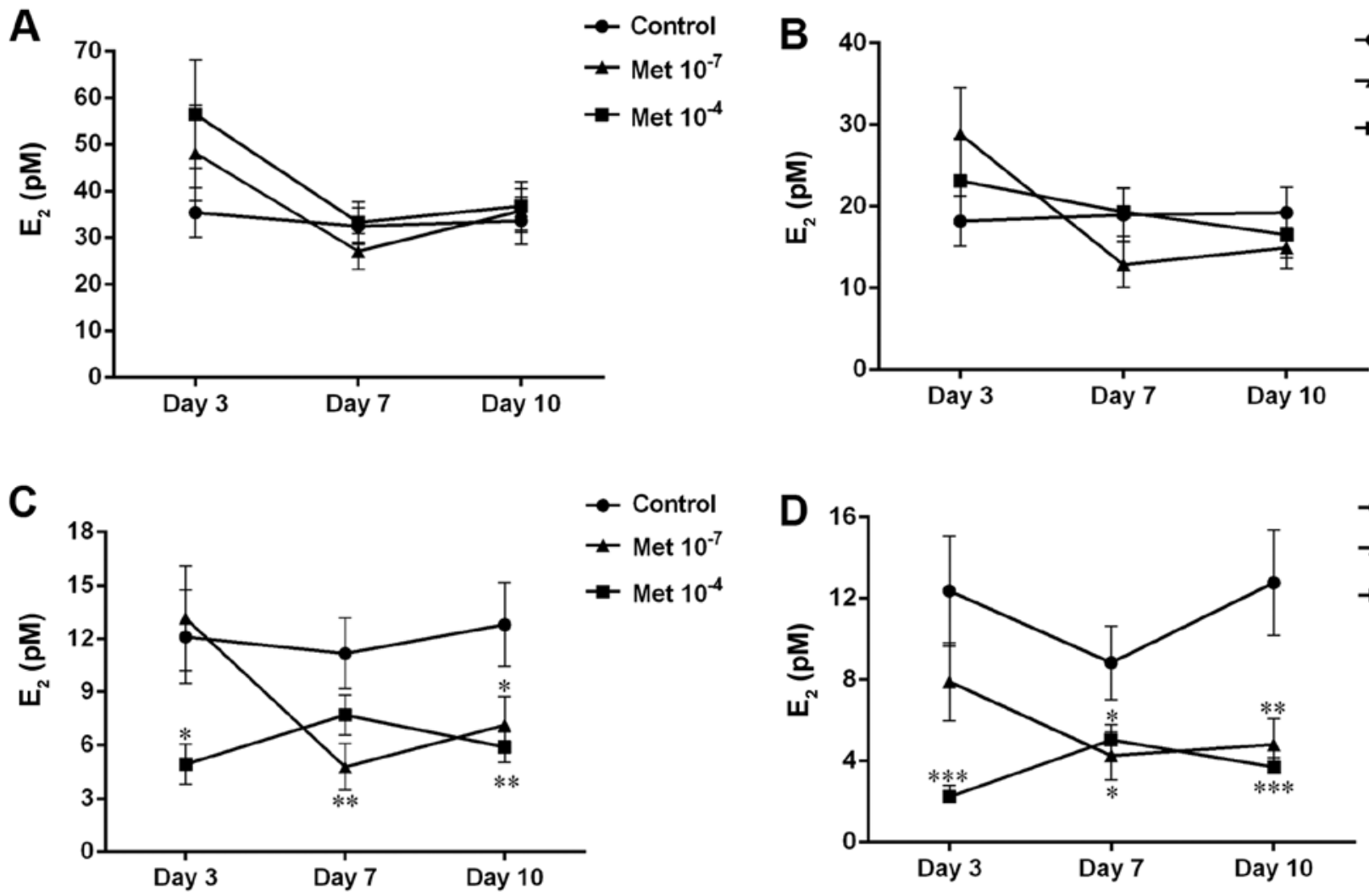

Control

Met $10^{-7}$

Met $10^{-4}$

Figure 4. Linear graph showing the levels of oestradiol $\left(\mathrm{E}_{2}\right)$ produced from cells cultured with different substrates over period of 10 days and in the presence of metformin at $10^{-7} \mathrm{M}(\mathbf{\Delta})$ or $10^{-4} \mathrm{M}(\mathbf{\square})\left(\mathrm{n}=6\right.$ experiments for each substrate). The medium was sampled on days 3,7 and 10 of culture and $\mathrm{E}_{2}$ levels were measured by radioimmunoassay (RIA). (A) Oestrone $\left(\mathrm{E}_{1}\right)(10 \mathrm{nM})$ was used as the substrate in measuring the conversion to $\mathrm{E}_{2}$. The addition of metformin at either dose did not alter the levels of $E_{2}$ produced. (B) Oestradiol sulphate $(E S)(10 \mathrm{nM})$ was used as the substrate in measuring the conversion to $E_{2}$. The addition of metformin at either dose did not alter the levels of $\mathrm{E}_{2}$ produced. (C) Androstenedione (ANDRO) $(10 \mathrm{nM})$ was used as the substrate in measuring the conversion to $\mathrm{E}_{2}$. Metformin at $10^{-7} \mathrm{M}$ significantly reduced $\mathrm{E}_{2}$ levels $\sim 50$-fold at days 7 and 10 in culture ( ${ }^{*} \mathrm{p}<0.05$, multiple $\mathrm{t}$-test). The higher dose of metformin $\left(10^{-4} \mathrm{M}\right)$ also reduced $\mathrm{E}_{2}$ levels $>50$-fold by the end of culture time (day 10), but was more effective sooner (day 3 ) ( $* \mathrm{p}<0.005$, multiple $\mathrm{t}$-tests). (D) Testosterone (TESTO) $(10 \mathrm{nM})$ was used as the substrate in measuring the conversion to $\mathrm{E}_{2}$. Metformin at $10^{-7} \mathrm{M}$ significantly reduced $\mathrm{E}_{2}$ levels $\sim 75$-fold on days 7 and 10 in culture $\left(\mathrm{p}<0.05,{ }^{* *} \mathrm{p}<0.005\right.$, multiple t-test). The higher dose of metformin $\left(10^{-4} \mathrm{M}\right)$ also reduced $\mathrm{E}_{2}$ levels by more than 75 -fold throughout the culture time but, similar to ANDRO, was more effective sooner (day 3$)(* * \mathrm{p}<0.0005$, multiple t-tests).

cant attenuation on days 3 and 10 ( $p<0.05$, one-sample t-test and paired t-test) but an unexplained increase (although statis- tically insignificant) on day 7, thereby mirroring the effect on the activity assay (Fig. 5A). This downregulating effect on total 

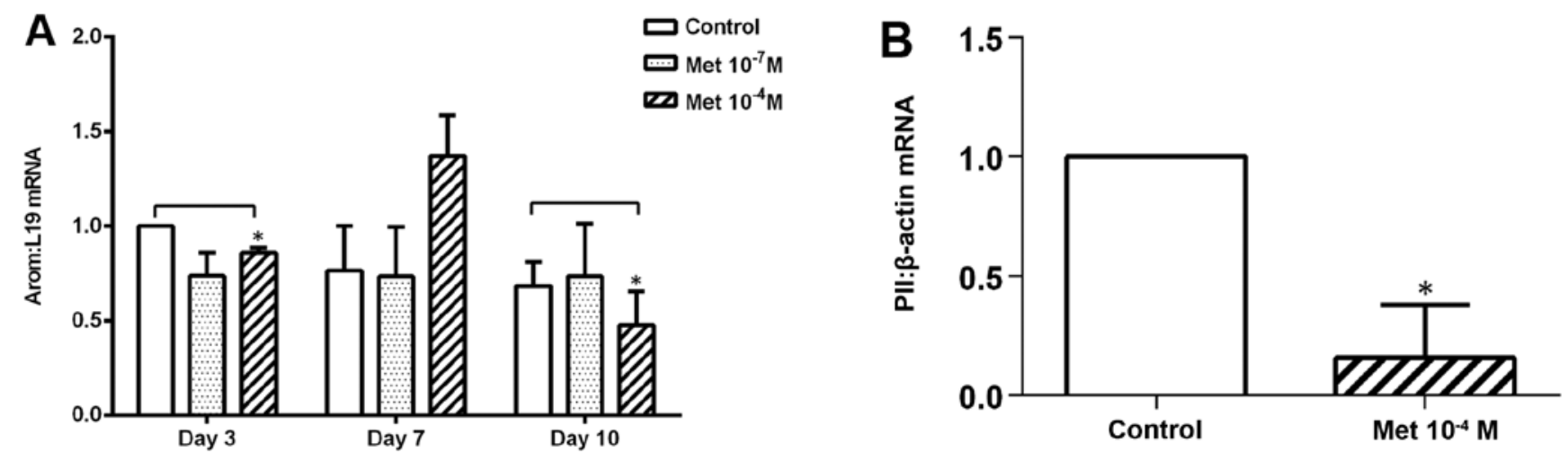

Figure 5. (A) Bar chart showing the mRNA levels of total aromatase measured relative to L19, after the cells were cultured for 10 days with/without metformin at $10^{-7} \mathrm{M}$ (dotted bar) and $10^{-4} \mathrm{M}$ (hatched bar) ( $\mathrm{n}=3$ experiments). RT-qPCR was carried out on days 3, 7 and 10 following exposure to metformin. Metformin at the higher dose $\left(10^{-4} \mathrm{M}\right)$ significantly reduced the total aromatase mRNA levels on days 3 and 10 of culture ("p<0.05, paired t-test), whilst the lower dose had no effect. (B) Graph showing mRNA levels of promoter II (PII) relative to $\beta$-actin, after treatment with the high dose of metformin $\left(10^{-4} \mathrm{M}\right)\left({ }^{*} \mathrm{p}<0.05\right.$, one-sample t-test).

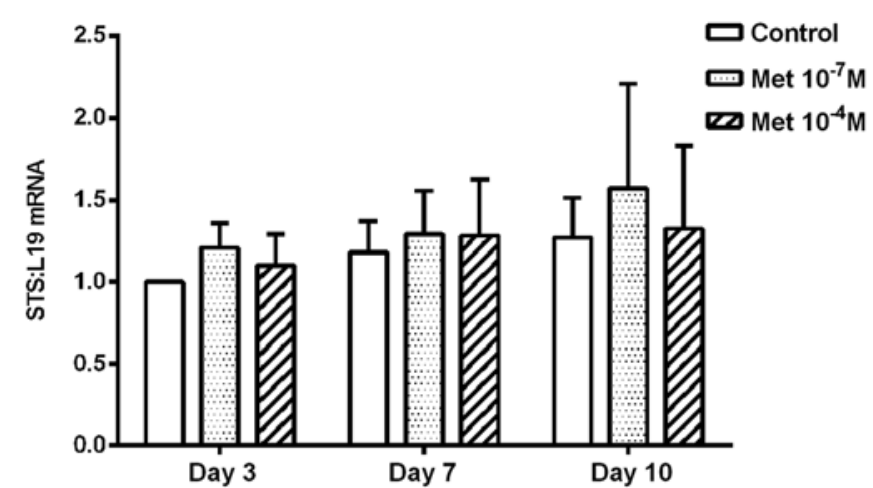

Figure 6. Bar chart showing the mRNA levels of steroid sulphatase (STS) relative to L19, after cells were cultured as described in Fig. 5A. Metformin at either dose had no effect on STS mRNA expression.

aromatase mRNA levels by metformin was via an attenuation of PII expression (Fig. 5B). By contrast, there was no effect of metformin, at either dose, on STS mRNA expression (Fig. 6).

\section{Discussion}

This study demonstrated that metformin reversed the effects of $\mathrm{E}_{2}$ on cell growth and potentiated the effects of rapamycin on the inhibition of cell growth. The activity of aromatase, which converts androgens to oestrogens, was significantly inhibited as was the mRNA expression of this enzyme. The conversion of ES and oestrone was not affected by metformin nor was the expression of oestrone sulphatase.

High doses of metformin have been shown to inhibit the growth of breast cancer cells (7-10), and our results confirm this. Whilst the effective dose of metformin used in vitro may exceed that measured in plasma, it does not preclude the supposition that metformin may accumulate locally in the tissue, thereby exceeding therapeutic levels determined in plasma. Of particular importance is that doses of metformin completely reversed the $50 \%$ increase in growth induced by $\mathrm{E}_{2}$ in MCF-7 cells. This agrees with studies on MCF-7 cells grown in 3-dimensional mammospheres, which represent a human breast cancer stem cell population. In a previous study, metformin reduced the number and size of mammospheres as well as the expression of oestrogen-stimulated OCT4 expression, a marker for cancer stem cells (31). Another study showed that metformin interacts additively with tamoxifen to reduce cell growth and decrease the expression of oestrogen receptor $\alpha(E R \alpha)(32)$. This effect of metformin on attenuating $\mathrm{E}_{2}$-driven growth is of particular significance, since oestrogens predominantly regulate the proliferation of $\mathrm{ER}^{+}$epithelial cells in breast tumours (33).

The National Cancer Institute finding of the antitumour activities of the mTOR inhibitor, rapamycin, have led to numerous studies on its potential use as an anti-proliferative agent in breast cancer (34). Therefore, the finding of an inhibition in the growth of MCF-7 cells by rapamycin in our study was as expected. However, what is novel is that rapamycin potentiated the anti-proliferative effects of metformin, even at a dose of $10^{-10} \mathrm{M}$ of rapamycin, which had no effect on growth. Rapamycin acts directly to inhibit mTOR and dephosphorylate the downstream proteins, p70S6 and 4EBP1, thereby inhibiting the translation and synthesis of proteins involved in growth, proliferation and survival $(34,35)$. Metformin (at similar doses used in this study) has been shown to inhibit mTOR through AMPK, thereby decreasing the phosphorylation of these downstream proteins (36). Therefore, the fact that both rapamycin and metformin inhibit mTOR, but though different signalling pathways $(3,37)$, highlights a potential therapeutic role for metformin to be used in conjunction with rapamycin analogues as anti-neoplastic agents.

The importance of oestrogen blockade in breast cancer treatment has been demonstrated by the clinical success of using aromatase inhibitors to treat ER-positive breast cancer $(17,33)$. The results of the assays for detecting steroidogenic enzyme activity showed that metformin significantly reduced the conversion of ANDRO and TESTO to $E_{2}$, both conversions involving aromatase. This was achieved at both the low dose $\left(10^{-7}\right)$ and the high dose $\left(10^{-4}\right)$ of metformin, and it must be emphasised that the low dose of metformin is well within plasma levels (38), demonstrating the effectiveness of metformin as an aromatase inhibitor. This was supported by the reduction in total aromatase mRNA levels via an attenuation of PII mRNA expression. The inhibition of metformin 
on $\mathrm{E}_{2}$ production was more marked when TESTO was used as a substrate compared to ANDRO, which probably reflects the fact that the conversion of ANDRO to $\mathrm{E}_{2}$ also requires 17 $\beta$-HSD either for the conversion of ANDRO to TESTO and/ or ANDRO to $E_{1}$ prior to its final conversion to $E_{2}$ (Fig. 1). Metformin appears to have a limited effect on 17 $\beta$-HSD activity, which is supported by the observation that metformin had no effect on $E_{2}$ levels compared to basal when $E_{1}$ is used as a substrate. Likewise, there was no reduction in STS activity by metformin, as measured by the conversion of ES to $E_{2}$, nor in STS mRNA expression. This is in agreement with other studies showing that metformin inhibited aromatase expression both in breast tissue $(19,20)$ and in the ovaries $(25)$. Interestingly, non-diabetic patients with breast cancer and taking $1,500 \mathrm{mg}$ metformin/day have shown a $38 \%$ reduction in free $\mathrm{E}_{2}$, but also a $29 \%$ reduction in free TESTO, again suggesting that metformin reduces steroid synthesis $(39,40)$.

Notably, in the experiments where $\mathrm{E}_{1} / \mathrm{ES}$ were used as substrates, the basal levels of $\mathrm{E}_{2}$ were considerably higher than when either ANDRO or TESTO was used. This highlights the importance of sulphatase and $17 \beta$-HSD pathways in the production of $E S / E_{1} / E_{2}$ in breast cancer $(27,41,42)$, and suggests that it may not be sufficient to only reduce aromatase levels in breast cancer in order to achieve anti-oestrogenic effects.

It is postulated that the cross-talk between hormone signalling and growth-regulating pathways, such as PI3K/Akt/mTOR, may lead to the constitutive activation of cell growth pathways, rendering patients resistant to hormone treatment (43). In order to tackle this problem, phase III trials are currently underway with rapamycin analogues, such as everolimus, in combination with anti-oestrogens, such as tamoxifen or anti-aromatase inhibitors, such as anastrazole (17,34). An in vivo rat model of mammary carcinogenesis, demonstrated that metformin was effective in inhibiting cancer as part of a multi-agent intervention, rather than a single agent (44). We conclude that metformin has a dual action on inhibiting the growth of breast cancer cells. First, by inhibiting cell proliferation at high doses, including that stimulated by oestrogen and, secondly, by inhibiting aromatase expression and activity, thereby reducing $\mathrm{E}_{2}$ levels and the growth-promoting effects of oestrogen on breast cancer. The findings presented in this study support a novel therapeutic action of metformin, in combination with rapamycin, as both an anti-proliferative agent and an aromatase inhibitor.

\section{Acknowledgements}

We would like thank Michael Lacey for his assistance with the steroid assays and cell culture. This study was supported by St. George's Hospital Charity, Medical Research Committee, St. George's Healthcare NHS Trust.

\section{References}

1. Ben Sahra I, Le Marchand-Brustel Y, Tanti JF and Bost F: Metformin in cancer therapy: A new perspective for an old antidiabetic drug. Mol Cancer Ther 9: 1092-1099, 2010.

2. Evans JM, Donnelly LA, Emslie-Smith AM, Alessi DR and Morris AD: Metformin and reduced risk of cancer in diabetic patients. BMJ 330: 1304-1305, 2005.

3. Gonzalez-Angulo AM and Meric-Bernstam F: Metformin: A therapeutic opportunity in breast cancer. Clin Cancer Res 16: 1695-1700, 2010.
4. Gallagher EJ and LeRoith D: Diabetes, cancer, and metformin: Connections of metabolism and cell proliferation. Ann NY Acad Sci 1243: 54-68, 2011.

5. Soranna D, Scotti L, Zambon A, Bosetti C, Grassi G, Catapano A, La Vecchia C, Mancia G and Corrao G: Cancer risk associated with use of metformin and sulfonylurea in type 2 diabetes: A meta-analysis. Oncologist 17: 813-822, 2012.

6. Col NF, Ochs L, Springmann V, Aragaki AK and Chlebowski RT: Metformin and breast cancer risk: A meta-analysis and critical literature review. Breast Cancer Res Treat 135: 639-646, 2012.

7. Zhuang Y and Miskimins WK: Cell cycle arrest in metformin treated breast cancer cells involves activation of AMPK, downregulation of cyclin D1, and requires $\mathrm{p} 27 \mathrm{Kip} 1$ or p21Cip. J Mol Signal 3: 18-29, 2008.

8. Phoenix KN, Vumbaca F and Claffey KP: Therapeutic metformin/AMPK activation promotes the angiogenic phenotype in the ERalpha negative MDA-MB-435 breast cancer model. Breast Cancer Res Treat 113: 101-111, 2009.

9. Alimova IN, Liu B, Fan Z, Edgerton SM, Dillon T, Lind SE and Thor AD: Metformin inhibits breast cancer cell growth, colony formation and induces cell cycle arrest in vitro. Cell Cycle 8: 909-915, 2009.

10. Feng YH, Velazquez-Torres G, Gully C, Chen J, Lee MH and Yeung SC: The impact of type 2 diabetes and antidiabetic drugs on cancer cell growth. J Cell Mol Med 15: 825-836, 2011.

11. Jalving M, Gietema JA, Lefrandt JD, de Jong S, Reyners AK, Gans RO and de Vries EG: Metformin: Taking away the candy for cancer. Eur J Cancer 46: 2369-2380, 2010.

12. Brown KA, Samarajeewa NU and Simpson ER: Endocrine-related cancers and the role of AMPK. Mol Cell Endocrinol 366: 170-179, 2013.

13. Li J, Kim SG and Blenis J: Rapamycin: One drug, many effects. Cell Metab 19: 373-379, 2014.

14. Vazquez-Martin A, Oliveras-Ferraros C and Menendez JA: The antidiabetic drug metformin suppresses HER2 (erbB-2) oncoprotein overexpression via inhibition of the mTOR effector p70S6K1 in human breast carcinoma cells. Cell Cycle 8: 88-96, 2009.

15. Chetrite GS, Cortes-Prieto J, Philippe JC, Wright F and Pasqualini JR: Comparison of estrogen concentrations, estrone sulfatase and aromatase activities in normal, and in cancerous, human breast tissues. J Steroid Biochem Mol Biol 72: 23-27, 2000.

16. Agarwal VR, Bulun SE, Leitch M, Rohrich R and Simpson ER: Use of alternative promoters to express the aromatase cytochrome P450 (CYP19) gene in breast adipose tissues of cancer-free and breast cancer patients. J Clin Endocrinol Metab 81: 3843-3849, 1996.

17. Barnadas A, Estévez LG, Lluch-Hernández A, RodriguezLescure A, Rodriguez-Sanchez C and Sanchez-Rovira P: An overview of letrozole in postmenopausal women with hormoneresponsive breast cancer. Adv Ther 28: 1045-1058, 2011.

18. Cook KL, Shajahan AN and Clarke R: Autophagy and endocrine resistance in breast cancer. Expert Rev Anticancer Ther 11: 1283-1294, 2011.

19. Brown KA, Hunger NI, Docanto M and Simpson ER: Metformin inhibits aromatase expression in human breast adipose stromal cells via stimulation of AMP-activated protein kinase. Breast Cancer Res Treat 123: 591-596, 2010.

20. Samarajeewa NU, Ham S, Yang F, Simpson ER and Brown KA: Promoter-specific effects of metformin on aromatase transcript expression. Steroids 76: 768-771, 2011.

21. Anastasius N, Boston S, Lacey M, Storing N and Whitehead SA: Evidence that low-dose, long-term genistein treatment inhibits oestradiol-stimulated growth in MCF-7 cells by down-regulation of the PI3-kinase/Akt signalling pathway. J Steroid Biochem Mol Biol 116: 50-55, 2009.

22. Rice S, Amon A and Whitehead SA: Ethanolic extracts of black cohosh (Actaea racemosa) inhibit growth and oestradiol synthesis from oestrone sulphate in breast cancer cells. Maturitas 56: 359-367, 2007.

23. Gilling-Smith C, Willis DS, Beard RW and Franks S: Hypersecretion of androstenedione by isolated thecal cells from polycystic ovaries. J Clin Endocrinol Metab 79: 1158-1165, 1994.

24. Willis D, Mason H, Gilling-Smith C and Franks S: Modulation by insulin of follicle-stimulating hormone and luteinizing hormone actions in human granulosa cells of normal and polycystic ovaries. J Clin Endocrinol Metab 81: 302-309, 1996. 
25. Rice S, Pellatt L, Ramanathan K, Whitehead SA and Mason HD: Metformin inhibits aromatase via an extracellular signal-regulated kinase-mediated pathway. Endocrinology 150: 4794-4801, 2009.

26. Rice S, Elia A, Jawad Z, Pellatt L and Mason HD: Metformin inhibits follicle-stimulating hormone (FSH) action in human granulosa cells: Relevance to polycystic ovary syndrome. J Clin Endocrinol Metab 98: E1491-E1500, 2013.

27. Utsumi T, Yoshimura N, Takeuchi S, Maruta M, Maeda K and Harada N: Elevated steroid sulfatase expression in breast cancers. J Steroid Biochem Mol Biol 73: 141-145, 2000.

28. Pfaffl MW: A new mathematical model for relative quantification in real-time RT-PCR. Nucleic Acids Res 29: e45, 2001.

29. Robert F, Fendri S, Hary L, Lacroix C, Andréjak M and Lalau JD: Kinetics of plasma and erythrocyte metformin after acute administration in healthy subjects. Diabetes Metab 29: 279-283, 2003.

30. Christensen MM, Brasch-Andersen C, Green H, Nielsen F, Damkier P, Beck-Nielsen H and Brosen K: The pharmacogenetics of metformin and its impact on plasma metformin steady-state levels and glycosylated hemoglobin A1c. Pharmacogenet Genomics 21: 837-850, 2011.

31. Jung JW, Park SB, Lee SJ, Seo MS, Trosko JE and Kang KS: Metformin represses self-renewal of the human breast carcinoma stem cells via inhibition of estrogen receptor-mediated OCT4 expression. PLoS One 6: e28068, 2011.

32. Berstein LM, Yue W, Wang JP and Santen RJ: Isolated and combined action of tamoxifen and metformin in wild-type, tamoxifen-resistant, and estrogen-deprived MCF-7 cells. Breast Cancer Res Treat 128: 109-117, 2011.

33. Ali S and Coombes RC: Endocrine-responsive breast cancer and strategies for combating resistance. Nat Rev Cancer 2: 101-112, 2002.

34. Seto B: Rapamycin and mTOR: A serendipitous discovery and implications for breast cancer. Clin Transl Med 1: 29, 2012.

35. Beretta L, Gingras AC, Svitkin YV, Hall MN and Sonenberg N Rapamycin blocks the phosphorylation of 4E-BP1 and inhibits cap-dependent initiation of translation. EMBO J 15: 658-664, 1996.
36. Dowling RJ, Zakikhani M, Fantus IG, Pollak M and Sonenberg N: Metformin inhibits mammalian target of rapamycin-dependent translation initiation in breast cancer cells. Cancer Res 67: 10804-10812, 2007.

37. Zakikhani M, Blouin MJ, Piura E and Pollak MN: Metformin and rapamycin have distinct effects on the AKT pathway and proliferation in breast cancer cells. Breast Cancer Res Treat 123: 271-279, 2010.

38. Lalau JD, Lemaire-Hurtel AS and Lacroix C: Establishment of a database of metformin plasma concentrations and erythrocyte levels in normal and emergency situations. Clin Drug Investig 31: 435-438, 2011.

39. Campagnoli C and Berrino F: Venturelli E, Abbà C, Biglia N, Brucato T, Cogliati P, Danese S, Donadio M, Zito G, Pasanisi P: Metformin dereases circulating androgen and oestrogen levels in nondiabetic women with breast cancer. Breast Cancer 13: 433-438, 2013.

40. Mansfield R, Galea R, Brincat M, Hole D and Mason H: Metformin has direct effects on human ovarian steroidogenesis. Fertil Steril 79: 956-962, 2003.

41. Foster PA, Chander SK, Newman SP, et al: A new therapeutic strategy against hormone-dependent breast cancer: The preclinical development of a dual aromatase and sulfatase inhibitor. Clin Cancer Res 14: 6469-6477, 2008.

42. Aka JA, Mazumdar M and Lin SX: Reductive 17beta-hydroxysteroid dehydrogenases in the sulfatase pathway: Critical in the cell proliferation of breast cancer. Mol Cell Endocrinol 301: 183-190, 2009.

43. Osborne CK and Schiff R: Mechansims of endocrine resistance in breast cancer. Annu Rev Med 62: 233-247, 2011.

44. Zhu Z, Jiang W, Thompson MD, McGinley JN and Thompson HJ: Metformin as an energy restriction mimetic agent for breast cancer prevention. J Carcinog 10: 17, 2011. 